\title{
Stylistic Analysis of Roald Dahl's Cinderella
}

\author{
Henni \\ D3 English Program, Faculty of Letters, Maranatha Christian University \\ J1. Suria Sumantri 65, Bandung \\ e-mail: henni_hk@yahoo.com
}

\begin{abstract}
The paper presents a stylistic analysis of a rhyme, Cinderella, taken from Dahl's rhyme collection, Revolting Rhymes. Roald Dahl is famous for his ability in creating extraordinary stories, in which linguistic elements, such as sounds and words, are manipulated to create an amusing story that has an unpredictable plot. The discussion covers an analysis of the narrative structure and the linguistic style applied in the rhyme, together with the discussion of the author's purpose of applying such style. From the analysis it is found out that the style Dahl applies in the rhyme is especially useful for foregrounding.
\end{abstract}

Key words: style, fairy tale, ideology

A work of literature can be analyzed using linguistics as the tool for analysis. According to Traugott and Pratt (1980) "linguistics can contribute a great deal to our understanding of a text. It can help us become aware of why it is that we experience what we do when we read a literary work ..." (p. 20). To do so, one of the options is doing a stylistic analysis. In doing a stylistic analysis, the researcher should formulate the research questions not only by asking about "what use is made of language" (Leech \& Short, 1981, p. 13) but also about the why and how, as Leech and Short (1981) formulate: "Why does the author here choose to express himself in this particular way?" and "How is such-and-such an aesthetic effect achieved through language?" (p. 13). Thus, it is clear that a stylistic analysis aims to explain the language used in a text in relation to its artistic function by providing tangible data not only mere interpretation of the researcher (Leech \& Short, 1981; Barry, 1995).

Authors of literary texts apply certain style in their writings to differentiate the language of literary texts from everyday language, called foregrounding. Among the various kinds of literary texts, one of the easiest to judge for certain foregrounding elements is poetry. This is because "The poet, more obviously than the prose writer, does 'interesting things' with 
language' (Leech \& Short, 1981, p. 2). Besides, in poetry, it is quite easy to see specific uses of language that will make us notice it as "something which distinguishes the language of poetry from everyday language, the distinguishing features of a prose style tend to become detectable over longer stretches of text"' (p. 3).

Among other writers for children's literature, Roald Dahl is one that is famous for his special style of writing. According to Birketviet (2006), Dahl's "tone of texts is confiding, conversational and funny" (p. 10). Although some of his works creates controversies, these controversies bring him fame and attract many readers especially adolescents to read his books (Royer, 1998). Dahl writes several novels and short stories for children, adolescents and adults. He also writes a collection of verses the Revolting Rhymes (1982) in which he retells six well-known fairy tales. What is special about this collection is that all the six fairy tales are twisted so that the contents of the verses are different from the original fairy tales. The first verse presented in the book is Cinderella.

The paper discusses Dahl's style of writing Cinderella. The discussion covers the form of the writing as a whole followed by the analysis of its linguistic aspects. The form includes a discussion on the narrative structure of the writing; while the linguistic aspects include the lexico-grammar and phonological aspects, cohesion, and the choice of words used in the text based on theories adapted from Leech and Short's (1981) and Toolan's (1996). Besides, there are analyses of the purposes of applying such style in each point of discussion based on Sutherlands's (1985) and Toolan's (1996) theories. To make the discussion clear, a theoretical framework is presented before the discussion.

\section{Narrative Structure}

According to Toolan (1996), a narrative describes events that happen in which some changes occur and one event is somehow related to other event that happens beforehand. Readers are usually aware of a narrative text as this kind of text has certain elements in certain order called the narrative structure. In Toolan's theory, the narrative structure of a text consists of six elements as follows:

a. An abstract, consisting of how the author introduces the story and arouses the reader's attention 
b. An orientation, consisting of sentences that describe the participants, time and place of the events

c. Complicating action, consisting of sentences that mentions the significant events of the story in sequence

d. Evaluation, consisting of comments to the events or things that do not directly deal with the events but more to the context of the events

e. A resolution, consisting of the answer to the question 'so what finally happened?'

f. A coda, consisting of the moral lesson of the story.

In typical narratives such as fairy tales, the 'default' narrative structure as mentioned above usually appear, although actually "not all of these six elements are equally crucial" and therefore, not all should exist in a narrative and the order of each element can be different. (Toolan, 1996, pp.136-140)

\section{Linguistic Analysis of Style}

\section{$\underline{\text { Lexico-Grammar Aspects }}$}

Leech and Short (1981) actually present detailed information on the lexical and grammatical categories that should be analyzed in a stylistic analysis. However, they acknowledge that these two categories can overlap. That is why in this paper, their theory is adapted into a combined elements covering both the lexical and grammatical aspects. The lexical aspect deals with the vocabulary used in the text. To differentiate lexical aspect with diction, the lexical aspect focuses more on the grammatical class of the words used, and the combination of the words to create phrases and clauses in the text (pp. 75-78).

\section{Cohesion}

According to Leech and Short (1981), cohesion deals with the "logical links between sentences" (p. 79). The logical links can be accomplished through the use of reference such as pronouns and articles, substitution, ellipsis, repetition and elegant variation. However, the paper limits the discussion of cohesive devices only to the use of reference. This is so to avoid an overlap with the third linguistic aspect, the diction, as two complementary theories are used. 
Diction

Toolan (1996) proposes in his theory that diction is "central to whatever is distinctive about a particular literary text" (p. 162). Colleridge considers the words used in a prose as 'words in their best order' while those used in a poem are 'the best words in the best order' (as cited in Toolan, 1996, p. 162). Thus, the choice of words an author makes in his or her writing must convey something that projects his or her voice behind the story.

\section{Ideology in Fairy Tales}

Just as any other text, a fairy tale also conveys the author's ideology. Sutherland (1985) is of the opinion that: "Like other types of literature, works written especially for children are informed and shaped by the authors' respective value systems, their notions of how the world is or ought to be." (p. 143). In classic fairy tales, such as Cinderella, "the heroine's value is measured in terms of her servitude, kindness, genteelness, and beauty. Ultimately these traits are rewarded with Cinderella's submission into a "valuable marriage" to that of a charming prince, whose worth is measured by his royal Eurocentric male status." (Harwood, 2008, p. 5).

Sutherland (1985) mentions that there are three ways ideologies are presented through children's literature: (1) the politics of advocacy, (2) the politics of attack, and (3) the politics of assent. Two contrasting ways are the politics of advocacy and the politics of attack, while the politics of assent is the mildest of the three. According to Sutherland (1985), The Politics of Advocacy puts forward the ideology by "pleading for and promoting a specific cause, or upholding a particular point of view or course of action as being valid and right... when ideologies are advocated in literature for children, authors are usually conscious of the values they are promoting." (p. 144). The kinds of ideologies to offer through this way are usually those concerning right conduct, good manners, religious and patriotic values. On the other hand, The Politics of Attack "is generated by the authors' sense of amusement, outrage, or contempt when they encounter something that runs counter to their concepts of right and wrong, good and evil, justice, fair play, decency, or truth" (p.145). Usually, the texts consisting the politics of attack are in the form of satires. As each 
author has different background, his or her politics of attack is "so highly personalized to individual authors" (p. 146). Some authors are blatant in their attacks; while some others writers are mild. However, writers of children's literature "tend to express their ideological assaults against targets of a more generalized or "universal" nature" (p. 144). As the mildest kind of way to promote an ideology, the politics of assent does not persuade the readers to agree as in the case of the two others; instead, it "simply affirms ideologies generally prevalent in the society" (p. 149).

\section{STYLISTIC ANALYSIS OF CINDERELLA}

The following sections discuss the stylistic analysis of Roald Dahl's Cinderella. The discussion is divided into two parts the Narrative Structure and the Linguistic Style (Lexico-grammar aspect, phonological aspect, cohesion, diction) of the rhyme. The rhyme being analyzed is put in the Appendix.

\section{Narrative Structure of Cinderella}

Dahl's Cinderella is written in the form of a poem - or rhyme - as the title of the book suggests. However, it follows the narrative structure that Toolan (1996) calls as the 'default' narrative structure of a fairy tale (p. 140). The first until the sixth lines of the rhyme creates the abstract of the story. The first and the second lines:

I guess you think you know this story.

You don't. The real one's much more gory.

create an understanding for the readers that the rest of the rhyme is about a story of Cinderella, but one that is different from the Cinderella story that the readers have already been familiar with. These two lines invite the readers to find out more about the "real" Cinderella story as in the third until the sixth lines Dahl argues that the well-known Cinderella story is "phoney" and made up "just to keep the children happy".

The orientation of the story begins in the ninth line, where Dahl starts to mention the character in the story "The Ugly Sisters". In the eleventh line until the thirteenth line, Dahl talks about the other character, "Cinderella" and the places where the story happens, that is, the "Palace" 
and the "slimy cellar". Lines sixteen and thirty also consist of the orientation, in which Dahl introduces two other characters, "The Magic Fairy" and "The Prince".

The complicating actions start in line fifteen up to line a hundred and four. The story begins by Cinderella's cry for help that invites the Magic Fairy to come for rescue (11. 15-29). By the help of the Magic Fairy, Cinderella can go to the Palace and dance with the Prince (11. 30-40). Then midnight comes and Cinderella has to leave the Ball. She looses one of her slippers when running from the Palace (11. 41-54). Up to this point, Dahl's version of Cinderella seems quite similar to the well-known Cinderella story. Yet, line fifty five shows the turning point of the story. The Prince leaves Cinderella's slipper unattended, so one of the Ugly sisters can exchange Cinderella's slipper with hers (11. 55-62). Thus, when the Prince is looking for the owner of the slipper by having every girl tries to fit it, it is only the Ugly Sister's foot that fits the slipper. As she is ugly, the Prince does not want to marry her and kills her, instead. Finding out about this, Cinderella is very disappointed. Moreover, the Prince wants to kill her as her appearance is not lady-like.

The re-appearance of the Magic Fairy (11. 105-106) marks the resolution of the story. She offers Cinderella a way out. Cinderella has become thoughtful and makes a wish for a decent man. This wise wish leads her to a happy life with a simple jam-maker. The resolution also serves as the coda of the story. Dahl seems to offer a message to the readers that money does not guarantee happiness.

The use of a conversational tone by the narrator of the story to address the readers, such as "I guess you think you know..." (1. 1), “... I fear" (1. 55), "Ah ha, you see ..." (1. 63) shows the evaluation part of the story. The evaluation makes the story more interesting as it creates a bonding between the teller of the story and the readers.

\section{Linguistic Style of Cinderella}

\section{$\underline{\text { Lexico-Grammar Aspect }}$}

Attributive adjectives are used whenever a character first appears in the story, for example "The Ugly Sister" (1. 9), "darling little Cinderella" (1. 11), "The Magic Fairy" (1. 16), and "The handsome Prince" (1. 30). Through the use of the attributive adjectives, Dahl creates the image of 
each character for the readers. Thus the readers will create a picture in their minds that the Sisters are ugly, Cinderella is a loveable young girl, the Fairy is able to do impossible things by magical power, and the Prince is handsome. Attributive adjectives are also used to describe the "silver slipper" (1. 27) which is regarded by the narrator of the story as a "dainty shoe" (1. 59). There are other attributive adjectives used in the text, such as "phoney one" (1. 3), "slimy cellar" (1. 12), "diamond brooch" (1. 26), "lovely nylon panty hose" (1. 28), "mighty flick" (1. 32), "manly chest" (1. 38), "pounding heart" (1. 50), "left foot" (1. 62), "normal foot" (1. 70), "trusty sword" (1.90), "bouncing head", (1.95) "dirty slut" (1. 103), "magic wand" (1. 107), "kind fairy" (1. 111), "decent man" (1. 115), "lovely feller" (1. 118), "simple jam maker" (1. 119), and "good home-made marmalade" (1. 120).

Besides attributive adjectives, there are also some predicative adjectives. When comparing the two versions of Cinderella story in the first six lines, Dahl uses several adjectives predicatively: "The real one's much more gory" (1. 2), "And made to sound all soft and sappy" (1. 5), "Just to keep the children happy" (1. 6). Other uses of predicative adjectives are in the sentences and clauses "I feel as rotten as can be" (1. 20), "...I am jealous" (1. 24), "The shoe was long and very wide" (1. 69), "also it smelled a wee bit icky" (1. 71), "The owner's feet were hot and sticky" (1. 72), "The Prince went white" (1. 79), "She is prettier" (1. 86), "This time I shall be more wary" (1. 112), and "And they were happy ever after" (1. 122).

From the list of adjectives used in the text both attributively and predicatively, it is clear that mostly the kind of adjective used describes physical and psychological states. As can be seen in the noun-adjective modifications in the above examples, most of the nouns used in the text are concrete nouns. Throughout the whole text, there are only three abstract nouns used: "luck" (1. 64), "tension" (1. 67), and "vain" (1. 74). Dahl tries to make his text as vivid as possible for the readers, so that the use of those adjectives combined with concrete nouns helps readers to visualize the story.

Dahl's purpose in selecting adjectives and nouns used in the text is also applied in his choice of verbs. Most of the verbs are hyponyms, so that specific actions are described in the text. The use of "departed" (1. 10) instead of went, "nibble" (1. 14) instead of bite, "bellowed" (1. 15) instead of shouted, "grabbed" (1. 44) instead of seize, "ripped" (1. 46) instead of torn, and "chopped" (1. 84) instead of cut helps the readers to have precise 
visualization of the story. The use of the specific verbs restricts the readers in interpreting the story so that the transfer of ideas from the author to the readers is in harmony.

\section{Phonological Aspect}

One of the special phonological characteristics Dahl applies in his Cinderella is that there are rhyming words in every two consecutive lines. The last word of the first line (story) rhymes with the last word of the second line (gory). The last word of the third line (know) rhymes with the last word of the fourth line (ago), and so on. This shows Dahl's competence in manipulating the language. The use of the rhyming words strengthens the nuance of the text as a rhyme or poem.

There are several uses of alliteration in the text. Throughout the text there are repetitions of the sound $/ \mathrm{s} /$ and $/ \mathrm{J} /$. The sound $/ \mathrm{s} /$ is repeated, for instance in the words "sound, soft, sappy, slimy and silver slipper"; while, the sound $/ / /$ is repeated in the words "wish, shout, flushed, shoe, swoosh and swish". Both the sounds $/ \mathrm{s} /$ and $/ \mathrm{J} /$ are fricatives. The use of fricatives which are made by opening the lips narrowly creates the impression of whispering. Thus, this shows as if the text conveys something that is a secret as the story is told by whispering. However, in the last part of the rhyme, there is alliteration of the sound $/ \mathrm{m} /$, such as in the words "more money, minute, married, simple jam maker, home-made marmalade, smiles". The use of the sound $/ \mathrm{m} /$ which is made by closing the lips creates the effect that the secret is all told and that the narrator's lips will be sealed after finishing telling the story.

\section{$\underline{\text { Cohesion }}$}

The first element of cohesion is the use of referents. The text begins by the use of the pronoun "I" which refers to the narrator of the story. The use of the pronoun "I" referring to the narrator also occurs in: "Then rather carelessly, I fear" (1. 55). Other use of the pronoun "I" is to refer to Cinderella: 'I feel as rotten as can be' (1. 20) and 'I want a dress! I want a coach!" (1. 25). From the two uses of the pronoun "I", it can be seen that the pronoun is used as the sensor in mental processes. However, there are other uses of "I". The first is to refer to the Prince: "I'll visit every house in town/Until I've tracked the maiden down" (11. 53-54). The other "I" is used 
to refer to the Magic Fairy: "That I will make it come about" (1. 110) and to refer to Cinderella "I'm wishing for a decent man" (1. 115). In the latter three references, the pronoun "I" acts as the agent of material processes. Based on the two different roles of the pronoun "I", it seems that Dahl wants to differentiate two groups, the one who can only sense something that happens and another who is able to do something based on one's own determination. The narrator's role as a sensor creates the impression that the narrator is innocent although what he is telling is a secret that is not nice. The use of "I" in reference to Cinderella as a sensor also creates the impression that Cinderella at the point of the story is considered immature, thus she cannot be the agent that can do something both for herself and her environment. The use of "I" as an agent shows the kind of people who can have the privilege to make his or her own decision to do something. They are those who have power and those who are mature. The first kind is represented by the Prince as someone from the Royal family, the ruler and by the Magic fairy as someone who has magical power. The second kind is represented by the changing Cinderella who is portrayed as a mature person as she is able to make a wise wish.

Another interesting thing is the use of the pronoun "they" in line seven to refer to the writer of the well-known Cinderella story. The use of "they" suggests that the writer is more than one person, so the readers will relate that the writer of the well-known story is the Grimms Brothers. Actually, it is not only the Grimms Brothers that write Cinderella story. Charles Perrault has created one version; in addition, there are also the Italian and Chinese versions of the story. The use of "they" then becomes ambiguous whether it refers to only the Grimms Brothers or to all writers of the wellknown story.

Concerning the use of articles in the text, in the first line of the text, the definite article "this" is used. The use of "this" which is a proximal deixis, refers to something that is near the speaker. The first line is the narrator's introduction of the story. Thus, the use of "this" refers to the story told by the narrator, not the well-known Cinderella story. By using "this" Dahl makes the readers aware that the Cinderella story told by the narrator is different from the well-known one. In mentioning the characters of the story, Dahl uses the article "the" followed by the role of the character in the story, except for the heroine. "The Ugly Sisters, The Magic Fairy, The Prince" are the nameless characters, but the use of the definite article "the" starting from the first time the character appears in the text makes the 
readers relate the characters to the similar ones in the well-known version. Yet, for the heroine Dahl uses the name Cinderella or Cindy.

$\underline{\text { Diction }}$

Starting from the title of his rhyme collection Revolting Rhymes, Dahl prepares the readers of encountering Sutherland's (1985) Politics of Attack. Upon hearing the word "Rhymes", most people will associate the word to the Twinkle-twinkle Little Star kinds of rhymes, which consist of play on words pleasing to the ear with nonsensical content created merely for children's enjoyment. Combined with the word "Revolting" which means "causing disgust or horror; extremely unpleasant", the rhymes must be something that is totally different from the 'traditional' rhymes readers are familiar with.

The first rhyme of the collection entitled Cinderella. Most readers are quite familiar with the story, but having the understanding that this rhyme is one of the Revolting Rhymes, the readers must have expected to encounter a different version of the story. This first expectation is strengthened by how Dahl opens the story: "I guess you think you know this story" (1. 1), continued by his claiming that his version is "the real one" (1. 2) and that the one the readers are familiar with is "phoney" (1. 3). Dahl's choice of the word "cooked up" strengthened his message that readers are deceived by the well-known Cinderella story which is made too "soft and sappy" (1. 5), only for the purpose of children's enjoyment. The use of the word "gory" (1.2) to describe Dahl's version of the story also emphasizes the usual kind of Dahl's writing, that is, "generally macabre in nature" (Royer, 1998, para. 1).

The use of the word "phoney" in the beginning of the text shows the colloquial nature of the text. Some other words such as "loo", "wee", "bizz", and "nut" also add to the colloquial nature. The first three words mentioned are uttered by the narrator. By using colloquial words, Dahl puts the readers closer to the text as if the narrator and the readers are having a dialog in an informal situation. The word "bizz" and "nut" are uttered by the Prince character in the story, showing that when loosing their temper, people from the royal family show informality in their conduct. Dahl here also communicates the message which often appears in his writings that heads of social institutions cannot be trusted to act intelligently (Royer, 1998). This is also shown in his choice of using the word "Disco" (1.23) to 
refer to the dancing in the Palace Ball. There is an extreme difference between a disco and a ballroom dance, in which a disco is a modern dance in which the dancers are free to express their own choreography, while a ballroom dance is a classical dance in which the dancers are strictly tied to certain rules in performing the dance. Having a disco in a Palace Ball is something that is not proper. The use of the word also emphasizes the informal nature of the text.

Dahl's politics of attack is also shown in the way he portrays the two major characters in the story, Cinderella and the Prince. Usually the heroines in classic fairy tales are portrayed as females who are beautiful, kind, and polite; but poor and receive bad treatment from the antagonists (Harwood, 2008). On the other hand, Dahl's portrayal of the heroine in his Cinderella is somehow different. The characteristics of kindness and politeness do not appear in the heroine. Upon her encounter with the Magic Fairy, Cinderella is portrayed as someone who is egocentric. Her pleading for things to make her ready for going to the Ball is not made in a polite manner, proved by Dahl's use of the words "shouted" (1. 22) to describe how Cinderella makes her wish to the Fairy. The way Cinderella describes her miserable condition is also not lady-like: "I fell as rotten as can be" (l. 20 ), accompanied with her action of beating "her fist against the wall" (1. 21). Cinderella's not lady-like manner is also shown when she is in the Palace dancing with the Prince. Dahl describes the scene as "She held him very tight and pressed/ herself against his manly chest/The Prince himself was turned to pulp/All he could do was gasp and gulp" (11. 37-39). The use of the phrase "held him very tight" and "pressed herself against his manly chest" shows sexually aggressive nature. The use of hyperbole in describing the condition of the Prince who is "turned to pulp" and can only "gasp and gulp" emphasizes that aggressive trait. Such characteristic is considered not noble for a lady, who is supposed to be passive and should not be the one who makes advances in pursuing a man and woman relationship.

Cinderella's not being lady-like continues in the midnight scene. She "shouted, "Heck!" (1. 41) and runs away. But the Prince tries to take her back by grabbing her dress which is then ripped off. Dahl describes that Cinderella "ran out in her underwear" (1. 47). The use of the word "underwear" emphasizes the heroine's contradiction with the stereotype of a lady. It is considered a disgrace for a lady to run out by wearing only her underwear, especially because there are people around. It is also noticed 
that Dahl uses the name "Cindy" when mentioning the heroine in these scenes.

It is also not clear whether the heroine in Dahl's story is beautiful or not. Dahl's description of the heroine is "darling little" (1. 11). Those two words do not say anything about her being beautiful. In the two lines before it, there is the phrase "The Ugly Sisters" (1. 9), the readers may assume that Cinderella must be the opposite of the Ugly Sisters; in this case, she is beautiful. Yet, the provision of "darling little" invalidates the assumption.

The classic stereotype of Prince Charming as the hero appears in the physical description of the prince as a "handsome prince" (1. 30). However, his code of conduct is not in accordance with the stereotype. In Dahl's version, the Prince is portrayed as someone who is cruel through the use of the repetition of "Off with her head" (1. 84) and "Off with her nut" (1. 104). The cruel and brutal nature is also confirmed by Cinderella's thought that the Prince "does that sort of thing for fun" (1. 102). The description of the Prince's action and the use of the phrase "for fun" here attacks the stereotype of a Prince, charming as a hero who saves the victim. Here, the Prince is portrayed as a horrible brute, and the phrase "for fun" implies the irresponsible nature of the Prince. As the character of the Prince in the story represents the authoritative figure, Dahl here presents "his contempt for social institutions" (Royer, 1998, para. 1).

The end of the story marks the turning point of the heroine's life. Her realization is that the Prince is not as good as what she expects; she wishes for a decent man. Her wish is granted by the Magic Fairy and she is married to "a simple jam-maker by trade" (1. 119). Dahl chooses to make quite a through description of this decent man. He speaks of him as "a lovely feller" (1. 118) and even what the man does for a living is also blatantly described. The readers know for sure that the man is a simple trader of home-made jam, and this kind of trader does not get much for his income. Yet, the narrator of the story says that the couple are happy as "Their house was filled with laughter/And they were happy ever after" (1l. 121-22). Through this, Dahl wants to affirm the old ideology that money cannot guarantee one's happiness. Dahl's converting to the 'traditional' ideology is also marked by his use of a very typical diction of fairy tales: "happy(ly) ever after".

Another change that happens at the end of the story is in the way the narrator of the story mentions the heroine's name. As pointed out above, when the heroine acts disgracefully, the narrator calls her "Cindy" (11. 19, 
$34,45,64,97,99,108)$. Yet, at the end of the story, when she realizes her mistake and is able to make a wise decision, the narrator of the story uses her full name "Cinderella" (1. 117). This marks the changes of the heroine's nature from being an immature little girl into a woman.

\section{CONCLUSION}

Based on the above discussion, it is found out that Dahl's style of writing is not merely his artistic expression in exploiting the English language. Dahl is able to create a story that can create a vivid visualization for the readers through the use of the adjectives, nouns and verbs in the story. Furthermore, his careful choice of words speaks of his belief that fairy tales are not true and that the portrayal of the heroes and the heroines in the fairy tales is too good to be true. Manipulation of sounds is also applied in his Cinderella, conveying certain effects such as whispering and being silent. In general, Dahl's choice of words, his way of combining the words into phrases and sentences to create the texture and content of the story, and his use of a 'conversational' narrator, show his ability in involving the readers into his story. In this way, Dahl is able to persuade his readers to believe in his politics of attack, without making the readers realize it. The readers are made to trust him as they notice that Dahl is still faithful to the traditional form, in which every two lines of the rhyme is rhyming. Besides, Dahl also keeps the default narrative structure of a fairy tale. His application of traditional form and narrative structure makes the readers believe that his rhyme is true as it meets the expectation of the readers. In conclusion, Dahl's Cinderella can be a good example of how stylistic analysis of a text can uncover the hidden ideology of the author of the text.

\section{REFERENCES}

Barry, P. (1995). Beginning theory: An introduction to literary and cultural theory. Manchester and New York: Manchester University Press.

Birketveit, A. (2006). Self interpretation and ideology in children's literature. Retrieved December 23, 2009, from http://www.hib.no/aktuelt/nyheter/ 2006/11/Birketveit.pdf

Harwood, D. (2008). Deconstructing and reconstructing Cinderella: Theoretical defense of critical literacy for young children. Language and Literacy, 10(2), 1-12. 
Leech, G., \& Short, M. H. (1981). Style in fiction: A linguistic introduction to English fictional prose. New York: Longman.

Royer, S. (1998). Roald Dahl. The ALAN Review, 26(1). Retrieved December 23, 2009, from http://scholar.lib.vt.edu/ejournals/ALAN/fall98/royer.html on

Sutherland, R. D. (1985). Hidden persuaders: Political ideologies in literature for children. Children's Literature in Education, 16(3), 143-157.

Toolan, M. (1996). Language in literature: An introduction to stylistic. New York: Oxford University Press.

Traugott, E. C., \& Pratt, M. L. (1980). Linguistics for students of literature. New York: Harcourt Brace Jovanovich.

\section{APPENDIX}

\section{The Rhyme}

Cinderella

I guess you think you know this story.

You don't. The real one's much gorier.

The phoney one, the one you know,

Was cooked up years and years ago,

5 And made to sound all soft and sappy

Just to keep the children happy.

Mind you, they got the first bit right,

The bit where, in the dead of night,

The Ugly Sisters, jewels and all,

10 Departed for the Palace Ball,

While darling little Cinderella

Was locked up in a slimy cellar,

Where rats who wanted things to eat,

Began to nibble at her feet.

15 She bellowed 'Help!' and 'Let me out!

The Magic Fairy heard her shout.

Appearing in a blaze of light,

She said: 'My dear, are you all right?' 
'All right?' cried Cindy.'Can't you see

20 'I feel as rotten as can be!'

She beat her fist against the wall, And shouted, 'Get me to the Ball!

'There is a Disco at the Palace!

'The rest have gone and 1 am jealous!

25 'I want a dress! I want a coach!

'And earrings and a diamond brooch!

'And silver slippers, two of those!

'And lovely nylon panty hose!

'Done up like that I'll guarantee

30 'The handsome Prince will fall for me!'

The Fairy said, 'Hang on a tick.'

She gave her wand a mighty flick

And quickly, in no time at all,

Cindy was at the Palace Ball!

35 It made the Ugly Sisters wince

To see her dancing with the Prince.

She held him very tight and pressed

herself against his manly chest.

The Prince himself was turned to pulp,

$40 \quad$ All he could do was gasp and gulp.

Then midnight struck. She shouted, 'Heck!

I've got to run to save my neck!'

The Prince cried, 'No! Alas! Alack!'

He grabbed her dress to hold her back.

45 As Cindy shouted, 'Let me go!'

The dress was ripped from head to toe.

She ran out in her underwear,

And lost one slipper on the stair.

The Prince was on it like a dart,

50 He pressed it to his pounding heart,

'The girl this slipper fits,' he cried,

'Tomorrow morn shall be my bride!

I'll visit every house in town

'Until I've tracked the maiden down!'

55 Then rather carelessly, I fear, He placed it on a crate of beer. 
At once, one of the Ugly Sisters, (The one whose face was blotched with blisters)

Sneaked up and grabbed the dainty shoe,

60 And quickly flushed it down the loo.

Then in its place she calmly put

The slipper from her own left foot.

Ah ha, you see, the plot grows thicker,

And Cindy's luck starts looking sicker.

65 Next day, the Prince went charging down

To knock on all the doors in town.

In every house, the tension grew.

Who was the owner of the shoe?

The shoe was long and very wide.

70 (A normal foot got lost inside.)

Also it smelled a wee bit icky.

(The owner's feet were hot and sticky.)

Thousands of eager people came

To try it on, but all in vain.

75 Now came the Ugly Sisters' go.

One tried it on. The Prince screamed, 'No!'

But she screamed, 'Yes! It fits! Whoopee!

'So now you've got to marry me!'

The Prince went white from ear to ear.

80 He muttered, 'Let me out of here.'

'Oh no you don't! You made a vow!

'There's no way you can back out now!'

'Off with her head! 'The Prince roared back.

They chopped it off with one big whack.

85 This pleased the Prince. He smiled and said,

'She's prettier without her head.'

Then up came Sister Number Two,

Who yelled, 'Now I will try the shoe!'

'Try this instead!' the Prince yelled back.

90 He swung his trusty sword and smack

Her head went crashing to the ground.

It bounced a bit and rolled around.

In the kitchen, peeling spuds,

Cinderella heard the thuds 
95 Of bouncing heads upon the floor, And poked her own head round the door.

'What's all the racket? 'Cindy cried.

'Mind your own bizz,' the Prince replied.

Poor Cindy's heart was torn to shreds.

100 My Prince! she thought. He chops off heads!

How could I marry anyone

Who does that sort of thing for fun?

The Prince cried, 'Who's this dirty slut?

'Off with her nut! Off with her nut!'

105 Just then, all in a blaze of light,

The Magic Fairy hove in sight,

Her Magic Wand went swoosh and swish!

'Cindy! 'she cried, 'come make a wish!

'Wish anything and have no doubt

110 'That I will make it come about!'

Cindy answered, 'Oh kind Fairy,

'This time I shall be more wary.

'No more Princes, no more money.

'I have had my taste of honey.

115 I'm wishing for a decent man.

'They're hard to find. D'you think you can?'

Within a minute, Cinderella

Was married to a lovely feller,

A simple jam maker by trade,

120 Who sold good home-made marmalade.

Their house was filled with smiles and laughter

And they were happy ever after 